\title{
Across borders: science and technology during the Cold War. An introduction
}

\author{
Edna Suárez-Díaz (*) Gisela Mateos $(* *)$ and Ana Barahona (***) \\ (*) orcid.org/0000-0003-2259-3110. Departamento de Biología Evolutiva. Facultad de Ciencias, \\ UNAM. ednasuarez@ciencias.unam.mx \\ $\left.{ }^{* *}\right)$ orcid.org/0000-0003-4288-4775. Centro de Investigaciones Interdisciplinarias en Ciencias y \\ Humanidades, UNAM. gisela.mateos@unam.mx \\ $(* * *)$ orcid.org/0000-0001-7765-6444. Departamento de Biología Evolutiva. Facultad de Ciencias, \\ UNAM.ana.barahona@ciencias.unam.mx
}

Dynamis

[0211-9536] 2015; 35 (2): 271-278

http://dx.doi.org/10.4321/S0211-95362015000200001

During the last decades we have witnessed an explosion of historical research on science during the Cold War period ${ }^{1}$. The availability of archival and other historical resources, and the recognition that the social history of this period cannot be written without acknowledging the contribution of science and technology, are some of the reasons behind the accumulation of historical research on this period. Moreover, salient features of contemporary science, including the primacy of governmental over private financing of scientific research, have their roots not only in the post war configuration of science, but in Cold War anxieties that defined research priorities between the late 1940s and the 1980s. National security concerns, and its correlate, international collaboration, are also part of what today define the practice of science around the globe. International and bi-national agencies were created in this period and played a crucial role in the internationalization and standardization of science.

1. Forman, Paul. Behind quantum electronics: National security as basis for physical research in the United States, 1940-1960. Historical Studies in the Physical and Biological Sciences. 1987; 18: 149-229; Krige, John. Atoms for Peace; scientific internationalism, and scientific intelligence. Osiris. 2006; 21: 161-81; Wang, Jessica. American science in an age of anxiety: Scientists, anticommunism, \& the Cold War. Chapel Hill: The University of North Carolina Press; 1999; Wang, Zuoye. Transnational science during Cold War. The case of Chinese/American scientists. Isis. 2010; 101: 367-377; Creager, Angela. Life Atomic: A history of radioisotopes in science and medicine. Chicago: University of Chicago Press; 2013. 
The recent historiographical interest on the «transnational» character of science intersects many of the Cold War themes. As mentioned above, international collaboration and the role of transnational agencies of patronage have been a constant subject in the field, as is the emphasis on the movement of people, materials, idea and instruments across national borders. It is true that these displacements did not start with the Cold War; however, the scale of international collaboration and interventions is not equaled by previous periods, and this fact reaches the historical profession too. A necessary reflexive stance should recognize that we, historians, are embedded in the discourse of globalization. In this context we suggest that transnational history could reconfigure the professional field of the history of science by making visible places and actors that remained invisible in national and Western-centered narratives, and particularly for the Cold War literature, on the bi-polar confrontation between the USSR and the United States.

In a recent volume on the transnational turn in the history of science, Simone Turchetti, Néstor Herran and Soraya Boudia ${ }^{2}$ claim that the amount of historical research on transnational science has not been accompanied by a thorough theoretical reflection on what this perspective offers to its practitioners. Answering the question of what the transnational turn is, they distinguish between a «set of tools» and a «way of seeing». In our view both aspects are closely related. The tool kit of the transnational historian seems to require enormous resources in terms of the number of people involved, financial support (to travel to different countries and archives), and linguistic skills, but also a set of questions that transcends the purely national context and follows practices across borders. Among these, how international or global scientific consensus has been produced, or how the standardization of techniques and instruments has taken place across different cultures, stand out. Internationalization also has other effects. Abir-Am, for instance, extends the impact of «transnational affiliates» in the emergence of the transdisciplinary field of Molecular Biology ${ }^{3}$. This special dossier includes cases that make reference to scientific projects in

2. Turchetti, Simone; Herran, Néstor; Boudia, Soraya. Introduction: have we ever been «transnational»? Towards a history of science across and beyond borders. British Journal for the History of Science. 2012; 45 (3): 319-336.

3. Abir-Am, Pnina. De la colaboración multidisciplinar a la objetividad transnacional: el espacio internacional, constitutivo de la biología molecular, 1930-1970. Arbor. 1997; 156 (614): 111-150. p. 112. 
East and West Germany, as well as in Mexico, Oxford, and the International Atomic Energy Agency (IAEA). However, these are not the usual local accounts. All of these projects reached beyond national frontiers: Mexico and its convoluted relation with the United States; East Germany and its relation to the USSR and West Germany; the IAEA and its failed attempts to transform agriculture through mutation breeding in the Third World; or the World Health Organization chromosome world surveys performed from the United Kingdom. The level of scientific exchanges that these papers illustrate challenges national traditional accounts of the period. These exchanges had been promoted starting in the late 1940s but intensified by the mid 1950s, as a result of development programs and the Atoms for Peace initiative.

Now, how did the global movement of knowledge between West-andEast, and North-and-South played out in the local configuration of Cold War scientific practices? Not all research carried out during this period can properly be explained by global or bi-polar tensions. Collaboration and international aid (as in development programs) played a crucial role. Moreover, the relation between North and South was equally politically charged as the East-West relation during the Cold War ${ }^{4}$. As a transnational model, the discourse of development not only dominated the North-South relations during the period, but created the very dichotomy of a developed and an underdeveloped world; the imagined geographies - representing the First World and the Third World-, cut the world along a line that implied the movement of technoscience (sometimes, second hand technologies, as shown in Jacob Hamblin's paper) in one direction, but the obligation to give and accept different things and symbols in two directions. The uses of nuclear technologies were understood as one of the high points of development policies during these decades; this fact was recognized by all parts involved in it. Is in this context that the Third World, which was target for most of the technical assistance programs at the IAEA, is also a

4. For instance, Mauricio Nieto and Alexis De Greiff argue that rather than a Cold War, Latin America suffered a hot war, reflected also in scientific developments. De Greiff, Alexis; Nieto Olarte, Mauricio. What we still do not know about South-North technoscientific exchange: Northcentrism, scientific diffusion, and the social studies of science. In: Doel, Ronald E.; Sörderquist, Thomas, eds. The historiography of contemporary science, technology and medicine. New York: Routledge; 2006, p. 239-259. 
fundamental actor for understanding the mobilization of practices, people, and resources during this period.

The Atoms for Peace program, launched at the end of 1953, has been fairly acknowledged as a key factor igniting science and technology exchange programs around the world. The IAEA was a crucial intermediary between owners and producers of atomic technoscience, and consumers, mainly - but not only- Third World countries. The 1955 Geneva Conference on the Peaceful Application of Atomic Energy was a turning point in this process ${ }^{5}$. In the papers of this dossier all of these exchanges were traversed, directly or non-directly, by Cold War concerns, in particular the uses and dangers of radiation and radioisotopes ${ }^{6}$.

Radioisotopes and reactors were, indeed, the main instruments in these itineraries, as were people: students and technical advisors traveled across borders in great numbers. Medicine and agriculture were some of the salient fields where these applications took place. By the 1960s, agriculture was a main international concern, in the context of «the war on hunger» and the Green Revolution, and a favorite area to invest in the Third World ${ }^{7}$. Two papers in this dossier deal with these issues. In Jacob Hamblin's paper, the Cold War intersects with development in the Global South; meanwhile

5. Osgood, Kenneth. Total Cold War. Eisenhower's secret propaganda battle at home and abroad. Lawrence: University Press of Kansas; 2006.

6. Creager, Angela. Tracing the politics of changing postwar research practices: the export of «American» radioisotopes to European biologists. Studies in the History and Philosophy of Biology and Biomedical Sciences. 2002; 33: 367-388; Creager, Angela. Radioisotopes as political instruments, 1946-1953. Dynamis. 2009; 29: 219-239; Creager, Angela; Santesmases, María Jesús. Radiobiology in the atomic age. Changing research practices and policies in comparative perspective. Journal of the History of Biology. 2006; 39: 637-647; Santesmases, María Jesús. Peace propaganda and biomedical experimentation: influential uses of radioisotopes in endocrinology and molecular genetics in Spain (1947-1971). Journal of the History of Biology. 2006; 39: 765-794; Herran, Néstor; Roqué, Xavier. Tracers of modern technoscience. Dynamis. 2009; 29: 123-130; Turchetti, Simone. A contentious business: industrial patents and the production of isotopes, 1930-1960. Dynamis. 2009; 29: 191-217; Herran, Néstor. Spreading Nucleonics: The isotope school at the atomic Energy research establishment, 1951-67. Bristish Journal for the History of Science. 2006; 39: 569-586.

7. Cullather, Nick. The Hungry World. America's Cold War battle against poverty in Asia. Cambridge: Harvard University Press; 2010; Hamblin, Jacob. Let there be light... and bread: the United Nations, the developing world and atomic energy's Green Revolution. History and Technology. 2009; 25 (1): 25-48; Zachmann, Karin. Atoms for peace and radiation for safety — how to build trust in irradiated foods in Cold War Europe and beyond. History and Technology. 2011; 27 (1): 65-90; Zachmann, Karin. Risk rays for an improved food supply? National and transnational food irradiation research as a Cold War recipe. Deutches Museum. Preprint 7; 2013. 
in her article, Karin Zachmann looks at the obviously «cold» context and contrasts between the two Germanies.

In his paper on "Quickening nature's pulse: Atomic agriculture at the International Atomic Energy Agency», Hamblin presents the IAEA program of «mutation breeders» (from different countries including Mexico and India) that claimed that radiation could enhance crop varieties, in particular of wheat and rice. Hamblin's story, however, is not one of successful development and achievements. As he states,

«Despite considerable opposition, and lacking evidence that atomic agriculture was worth the investment, the IAEA nurtured (this) scientific field, a community of experts and an imagined version of the future that put humans in control of their destiny, powered by the atom» 8 .

Paradoxically, some of these research projects designed in places like the United States and Sweden were not designed to eliminate hunger in the world, but advance research agendas that were dangerously closed to Lysenkoism. Radiation was a tool to genetically transform species, suggesting that social progress could be attained through directed evolution. The IAEA's «International Mutation Group», like other development programs ignored the local context, and promoted applications without consultation with local communities and peasants around the world 9 .

In Zachmann's «Peaceful atoms in agriculture and food: How the politics of the Cold War shaped agricultural research using isotopes and radiation in post war divided Germany» we learn that the Federal Republic of Germany radioisotope distribution started in 1949, under British occupation (the radioisotopes coming from the Atomic Energy Research Establishment at Harwell). Experiments using radiation in medicine, biochemistry, agriculture and biophysics took place in Western Germany at different Max Planck Institutes during those first years. Meanwhile, the situation at the German Democratic Republic suffered from the embargo of British authorities to East Europe. It was not until 1954 that the embargo was lifted as a consequence of the Atoms for Peace initiative, which also

8. Hamblin, Jacob Darwin. Quickening nature's pulse: Atomic agriculture at the International Atomic Energy Agency. Dynamis. 2015; 35 (2): 389-408

9. Escobar, Arturo. Encountering Development. The making and unmaking of the Thirld World. Princeton: Princeton University Press; 1994; Moon, Suzanne. Takeoff or self-sufficiency ideologies of development in Indonesia, 1957-1961. Technology and Culture. 1998; 39 (2): 187-212. 
had consequences for the repatriation of German nuclear scientists from the USSR to the GDR. However, scientists from East Germany could not attend the radioisotope courses delivered in Harwell until 1959, due to security issues; moreover, radioisotope distribution in this country came from Moscow. This is a clear instance in which the Cold War distinctively shaped the travels of people, materials, and practices across different borders. More permeable travels took place within each block, but the wall between East and West was not completely solid. Starting in 1955 the first shipment from Moscow arrived at the Institute for Agricultural Chemistry in Jena, for studying phosphate fertilizers intake and use in plants. But agricultural research at the GDR was modeled after research originally developed at nutrition science and agriculture centers at the FRG, thus showing that despite the Iron Curtain there was an effective scientific exchange between the two Germanies. Notwithstanding the differences in time and sources, at the end «the institutional structures for atomic and nuclear research were similar in East and West Germany»; in both states the financing in applications in agriculture came exclusively from the federal government, and focused on a small set of problems and applications.

Other walls were less visible but not less solid. The relation between Mexico and its northern neighbor has been a historically complex one. The article by Gisela Mateos and Edna Suárez-Díaz on «Clouds, airplanes, trucks and people: carrying radioisotopes to and across Mexico» illustrates how radioisotopes (as commodities and as atomic trash) and people itineraries took place between Mexico and the United States, advancing the not always well-aligned interests of both partners. These radioactive materials shaped and contributed to Mexican nuclearization during the 1950's and 1960's: as in other countries, radioisotopes were distributed to Mexico from Oak Ridge National Laboratory (starting in 1949), but by the late 1950s radioactive fallout became an excuse to train a first generation of radiochemists. Then, by the late 1960s, with the help of the IAEA, Mexico acquired a US-made research reactor, which enabled it to produce most of the national consumption of these materials, to be used in medicine, agriculture, and research. This process took place within a discourse of nationalism and modernity of the Mexican State, in such a way that the uses of nuclear technologies were restricted and intimately related to the neutral and pacifist position of Mexico in the international arena.

Finally, there is the need to reflect on the historical agents of transnational science. The «scientist-diplomat-politician» who played a role in the 
construction of institutions and interventions across national borders, as well as the institutions that made this possible. Here, history of science comes close to diplomatic history, and the state and the nation are part of the globalization process. Two papers in this dossier deal with these issues. Ana Barahona's paper on «Transnational science and collaborative networks. The case of Genetics and Radiobiology in Mexico, 1950-1970» shows the role played by Mexican physician-turned-geneticist Alfonso León de Garay in the foundation of the first Radiobiology and Genetics Program (PGR) in the country due to his belonging to an international network on human genetics as well as to the Mexican scientific elite of the 1960s. De Garay's work cannot be understood without paying attention to the development of nuclear physics and the creation of the National Nuclear Energy Commission under the auspices of the IAEA, and to the international movement towards the pacific uses of nuclear energy. This paper shows how de Garay, while studying in London at the Galton Laboratory was acquainted with the pioneers of nuclear physics in Mexico who were promoting and negotiating the creation of a National Nuclear Center with federal funds, and who prompted him to return to Mexico to found the PGR. The analysis of scientific networks that de Garay belonged to, indicates the authority that this conferred upon him at a local level to further his interests and pursue his personal agenda. It also allowed him to promote his ideas outside of local geographical boundaries thanks to the moral and epistemic authority he had acquired by studying abroad, and through his personal relationships.

Meanwhile, Soraya de Chadarevian's paper on «Human population studies and the World Health Organization» shows the key role played by the WHO in shaping transnational projects in the life sciences which responded to Cold War concerns about the effects of radiation on human populations and the future of human kind. As a request of the WHO, American re-known human geneticist and founder of the first Department of Human Genetics at the University of Michigan, James Neel met in Ann Arbor with other human geneticists and identified two urgent investigations that «could profit significantly from WHO support as they both relied on the cooperative efforts of several countries»; one was a comparative study of congenital malformations conducted by British human geneticist Alan Stevenson that was conceived as a step toward understanding the occurrence and types of congenital malformations found in stillborn and live-born infants; the other was on the genetic characterization of «primitive 
groups» and «isolated populations». With the aid of former postdoc student Francisco M. Salzano, Neel embarked on an extended study of Indian tribes in Brazil, to collect all possible data on the quickly vanishing populations to study the deep history of humanity. Neel asked for WHO support and recognition, hoping that this study could be served as a working model for further studies in other parts of the world. Neel, Stevenson and their colleagues expected the legitimization that institutions like the WHO could provide them to pursue their personal agendas. As de Chadarevian shows these scientists «regarded the WHO as an ideal frame in which international cooperative studies could be conducted», and used their personal links to gain international legitimization for their work.

The five papers included in this dossier aim to contribute to a further understanding of the role of across-the-border travels, itineraries, and transactions that characterized technoscientific practices during the Cold War. They do so by broadening the geographical scope of historical studies, and contextualizing the local within the global events, concerns, and policies of the period, especially through the role of international agencies in the construction of almost-global networks of science. The papers also share a way of seeing, of interrogating the global projects and goals in their local happening and the tensions produced between them. The result, we must say, is not a triumphalist view of science and technical assistance, but one of mixed results. Personal agendas are furthered, development programs fail, the scientific community is seldom truly international, while at the same time the growth of international networks allowed the training of a new generation of scientists around the world, and the incorporation of places, technologies, and actors transformed Cold War technoscientific practices by introducing different local priorities and ways of doing. 